\title{
Profissão docente: representações sociais compartilhadas por professores(as) na rede Facebook
}

\author{
Thaiz Reis Albuquerque de Castro \\ Universidade Federal de Pernambuco - UFPE, Brasil \\ Laeda Bezerra Machado \\ Universidade Federal de Pernambuco - UFPE, Brasil \\ Apoio e financiamento: Conselho Nacional de Desenvolvimento \\ Científico e Tecnológico - CNPq
}

\section{RESUMO}

Este artigo analisa comunicações em torno da profissão docente compartilhadas por professores na rede social Facebook. Adota como referencial a Teoria das Representações Sociais. Tratase de um estudo de abordagem qualitativa, delineado como pesquisa documental. Da rede social Facebook, foram selecionadas e analisadas, a partir da técnica de análise de conteúdo, cinco páginas relacionadas à docência. Nas representações sociais do ser professor identificadas neste artigo, ganharam relevo elementos como excesso de trabalho e múltiplas exigências por parte da escola e sistemas. Os professores destacam os limites de ordem institucional enfrentados no dia a dia da profissão. Eles vivenciam limitações materiais e didáticas nas escolas e, muitas vezes, precisam trabalhar na base do improviso. Os elementos que comprometem o trabalho docente explicitados neste artigo são indicativos de que não se deve culpabilizar unicamente o docente pelos problemas educacionais. Quando agimos dessa forma, ignoramos os obstáculos interpostos ao exercício da profissão.

PALAVRAS-CHAVE: Representações Sociais. Profissão Docente. Facebook.

\section{THE IMPORTANCE OF GOVERNMENT PROJECTS IN TEACHING INITIAL TRAINING: A CASE STUDY}

\begin{abstract}
This article analyzes communications around the teaching profession shared by teachers on the social network Facebook. It adopts the Theory of Social Representations as a reference. This is a qualitative study, designed as documentary research. From the social network Facebook, five pages related to teaching were selected and analyzed using the content analysis technique. In the social representations of being a teacher identified in this article, elements such as overwork and multiple demands on the part of the school and systems have gained prominence. The professors highlight the institutional limits faced in the profession's daily routine. They experience material and didactic limitations in schools and often need to work on the basis of improvisation. The elements that compromise the teaching work explained in this article are
\end{abstract}


indicative that one should not blame the teacher alone for the educational problems. When we act in this way, we ignore the obstacles to the exercise of the profession.

KEYWORDS: Social Representations. Teaching profession. Facebook.

\section{PROFESIÓN DEL PROFESOR: REPRESENTACIONES SOCIALES COMPARTIDAS POR LOS PROFESORES EN LA RED DE FACEBOOK}

\section{RESUMEN}

Este artículo analiza las comunicaciones sobre la profesión docente que comparten los docentes en la red social Facebook. Adopta la Teoría de las representaciones sociales como referencia. Este es un estudio cualitativo, diseñado como investigación documental. Desde la red social Facebook, se seleccionaron y analizaron cinco páginas relacionadas con la enseñanza utilizando la técnica de análisis de contenido. En las representaciones sociales de ser un maestro identificado en este artículo, elementos como el exceso de trabajo y las múltiples demandas por parte de la escuela y los sistemas han cobrado importancia. Los profesores destacan los límites institucionales que se enfrentan en la rutina diaria de la profesión. Experimentan limitaciones materiales y didácticas en las escuelas y a menudo necesitan trabajar sobre la base de la improvisación. Los elementos que comprometen el trabajo docente explicados en este artículo son indicativos de que no se debe culpar solo al maestro por los problemas educativos. Cuando actuamos de esta manera, ignoramos los obstáculos para el ejercicio de la profesión.

PALABRAS CLAVE: Representaciones Sociales. Profesión Docente. Facebook.

\section{INTRODUÇÃO}

$\mathrm{Na}$ atualidade, presenciamos amplos e rápidos avanços das tecnologias que afetam diretamente as nossas relações sociais. A evolução da internet e das suas redes sociais online vem proporcionando um novo cenário para as comunicações entre indivíduos e seus grupos e, por sua vez, uma nova era para elaboração e construção de representações sociais. (MAZZOTTI; CAMPOS, 2011). As representações sociais são uma série de proposições que permitem classificar coisas ou pessoas, descrever seu caráter, explicar seus sentimentos e ações. Conforme Arruda (2011, p. 348), elas funcionam "como uma rede de ideias, metáforas e imagens, amarradas de forma mais ou menos frouxa e, portanto, mais móveis e fluidas que teorias".

O presente artigo decorre de uma pesquisa mais abrangente que analisou as representações sociais da profissão docente em comunicações entre professores (as) na rede social Facebook. Nele, abordamos os elementos das representações mais relacionados aos desafios enfrentados no exercício da profissão docente.

De modo geral, a trajetória da profissão docente é marcada pela feminização, pelo idealismo, pela vocação, o cuidar da criança, divinização do ato pedagógico e desvalorização 
social. (LENGERT, 2011). Nas últimas décadas, tem sido comum o sentimento de insatisfação dos professores, que tem se acentuado devido às políticas que acabam por enfatizar a desprofissionalização dos professores, a pouca valorização da formação específica, desrespeito à legislação que prevê planos de cargos e salários, entre outros. Segundo Nóvoa (2017), a desprofissionalização se manifesta de maneiras variadas, desde níveis salariais baixos e difíceis condições nas escolas, assim como pelos processos de burocratização e de controle intensificados do trabalho docente que contribuem para o desprestígio da profissão através da desvalorização das dimensões da profissionalidade.

Conforme Castro e Machado (2018), estudos recentes sobre a profissão docente, desenvolvidos no âmbito da Teoria das Representações Sociais, apontam que a docência vem sendo representada como uma profissão marcada por vários dilemas cotidianos, tais como desvalorização social, múltiplas funções e precariedade das condições de trabalho.

Partimos da compreensão de que as redes sociais online são espaços de interação entre diversos grupos sociais, incluindo os (as) professores (as), e nelas eles se relacionam, comunicam e interagem, trocando experiências e desabafando, dentre outras coisas, sobre os desafios da rotina da profissão. Entendemos que uma análise das representações sociais veiculadas nas comunicações entre professores (as) nessas redes nos permite desvelar como esse grupo compreende e explica o sentido do trabalho docente, os fatores que os conduzem ou não a um bom desempenho profissional, os vínculos que mantêm com sua profissão, como definem sua identidade social e as expectativas que têm para com o futuro da profissão.

\section{AS REPRESENTAÇÕES SOCIAIS}

As representações sociais têm em seu centro a comunicação, pois sua origem está no espaço de interseção entre a comunicação social e o indivíduo no seu contexto. São produtos das comunicações sociais, construídas coletivamente nas interações sociais, com valores e ideias que circulam na sociedade em diversos âmbitos, incluindo nos meios de comunicação via internet, como as redes sociais online. Considerando a estrutura simples e espontânea das comunicações em tais redes, optamos por analisar as representações veiculadas nas comunicações entre professores com base nas suas dimensões e nos seus processos geradores (MOSCOVICI, 2012).

Em relação às dimensões, Fagundes, Zanella e Torres (2012) definem que as representações sociais são compostas pelas atitudes, ou seja, possibilidade de identificar posições favoráveis ou não em relação a determinado objeto; pela informação, no caso, a 
qualidade e quantidade de conhecimento que o sujeito/grupo tem sobre o objeto; e ainda pelo campo de representação ou imagem que permite a visualização de conhecimentos e atitudes organizados em forma de teoria.

Quanto aos processos geradores, são denominados objetivação e ancoragem. O processo de objetivação torna material um conceito não familiar, dessa forma, tem a propriedade de tornar concreto o abstrato, de materializar algo simbolicamente. Por sua vez, o processo de ancoragem significa classificar e atribuir um nome, que, sendo assim, permite transferir algo estranho de um espaço externo ao nosso sistema de categorias para dentro dele e colocá-lo em confronto com o paradigma da categoria que acreditamos ser a mais adequada. (GALLI, 2012).

Furtado (2009) destaca que a comunicação influi de modo essencial na formação, delineamento e modificação das representações sociais, ou seja, nas concepções de mundo. Dessa forma, a comunicação desempenha papel relevante ao proporcionar aos indivíduos e grupos noções sobre os valores relativos às suas atividades humanas e aos seus objetos significativos.

\section{REDES SOCIAIS ONLINE E FACEBOOK}

De acordo com Silva (2016), o uso da internet proporcionou diversas mudanças em nossa sociedade e, dentre elas, destacamos as novas possibilidades de comunicação entre os indivíduos, pois no espaço virtual é possível estabelecer contato até com pessoas que estão distantes geograficamente, mas conectados a uma mesma rede social.

Uma rede social, seja ela de caráter offline (construída nos espaços concretos de convivência) ou online (concebida nos espaços virtuais e mediada por tecnologias digitais), é definida como uma estrutura social composta por pessoas ou coletivos, conectados por um ou vários tipos de relações, que partilham valores e objetivos comuns. (CUNHA, 2016).

Redes sociais online estão baseadas em uma estrutura flexível, dinâmica e autoorganizável, com relações horizontais de cooperação, que permitem aos grupos sociais que, por alguma razão se sintam intimidados ou isolados no mundo real, possam adotá-las como espaços de apoio e cooperação. Nesse caso, os professores, enquanto grupo que se sente desprestigiado socialmente, encontra nessas redes um ambiente para apoio entre colegas de profissão. (TOMAÉ; ALCARÁ; DI CHIARA, 2005). Atualmente, estima-se que, ao redor do mundo, existam 3,4 bilhões de usuários ativos nas redes sociais na internet (NEILPATEL, 2019). No Brasil, aproximadamente $58 \%$ da população têm pelo menos um perfil nessas redes sociais (NEILPATEL, 2019).

O Facebook se destaca como a maior rede social online do mundo (BELING, 2016). 
Em sua estrutura, disponibiliza os mecanismos de curtir, compartilhar e comentar, que deixam mais sofisticadas as comunicações entre usuários. O curtir é uma forma rápida de estabelecer, sem palavras, algum nível de reconhecimento ou valorização. O compartilhar tem como principal função dar visibilidade para a publicação, ampliando o seu alcance. E o comentar é uma prática de comunicação mais explícita, que traz uma efetiva contribuição para a conversação. O grande quantitativo de interações através desses recursos reflete o interesse do grupo para com a temática abordada nas publicações. (RECUERO, 2014).

Além desses recursos, o Facebook apresenta diversas páginas nas quais são abordadas temáticas de interesse de variados grupos. Muitas dessas delas são voltadas para professores, de todos os níveis e modalidades de ensino, que se agrupam nesses espaços para interagirem em publicações que tratam sobre o cotidiano da profissão e acabam veiculando representações sociais do ser professor. Tomamos essa rede social como espaço de investigação, dentre outras razões, devido à sua ampla adesão por parte os professores.

\section{MÉTODO}

O presente artigo resulta de uma pesquisa de abordagem qualitativa, que privilegia os significados atribuídos pelos sujeitos aos diferentes objetos. (LÜDKE; ANDRÉ, 1986). Quanto ao procedimento, configura-se como documental, pois contempla a análise de materiais que não são de caráter científico e não receberam nenhum tratamento analítico prévio. (GIL, 2006). Estes materiais são imagens, de variados gêneros, publicadas nas páginas frequentadas por professores no Facebook, bem como os comentários de professores referentes às mesmas.

A escolha do Facebook como fonte desse material documental se deu por essa rede social ter uma ampla adesão de professores de todo o país; apresentar publicações que abordam diversos aspectos do cotidiano da docência; e possuir em sua estrutura noções de público e privado mais fluidas e aproximadas, o que promove uma comunicação mais simples e espontânea entre usuários e uma maior facilidade ao pesquisador ao acesso dos seus perfis.

Selecionamos cinco páginas com base nos critérios referentes à escolha dessa rede e, ainda, por apresentarem denominações variadas relacionadas ao ser professor, de modo a não nos limitarmos àquelas que apresentassem títulos negativos ou jocosos para com a docência. Assim, foram selecionadas as seguintes páginas para análise: "Profissão Professor" (+777.000 seguidores), "Profissão=Professora" (+402.000 seguidores), "Professor por Vocação" (+322.000 seguidores), "Pedagogia por Amor" (31.348 seguidores) e "Professores Sofredores" (+1.500.000 seguidores). 
As páginas "Profissão Professor" e "Profissão=Professora" foram escolhidas por apresentarem uma denominação que é sugestiva da docência como profissão e, no caso da segunda, por sugerir que a docência é uma profissão feminina. As páginas "Professor por Vocação" e "Pedagogia por Amor" foram escolhidas por qualificarem positivamente a profissão. E, por fim, a página "Professores Sofredores" foi selecionada por sua denominação de teor pessimista para com a docência.

O levantamento do material para análise (imagens e comentários relacionados) foi feito de forma decrescente, ou seja, partimos das publicações mais recentes para as mais antigas, de modo a obtermos um acervo atualizado. Para a seleção dos comentários, íamos, um por um, verificando o Perfil Público do seguidor que o publicou a fim de identificar características como sexo e localização geográfica. E, para análise, fizemos uso da técnica da análise de conteúdo temática. Segundo Bardin (2016, p. 200), a categorização temática consiste em "operações de desmembramentos do texto em unidades, em categorias segundo reagrupamentos analógicos".

O material recolhido dessas páginas importou um corpus composto, no total, por 24 imagens e 94 comentários referentes, publicados entre os anos de 2016 a 2018, que culminaram em três grandes categorias temáticas acerca do objeto investigado: Referências à escolha profissional, Desvalorização e Precarização profissão, Desafios da rotina docente. Nos limites deste artigo, abordamos os elementos dessas representações concentrados da terceira categoria, os quais aludem aos desafios da rotina docente. Para isto, analisamos quatro imagens e 15 comentários discutidos em dois eixos de sentido: Falta de recursos materiais e didáticos e Excesso de exigências.

\section{RESULTADOS E DISCUSSÃO}

Os desafios da rotina docente estão relacionados à falta de recursos materiais e didáticos, das relações de trabalho na escola e sala de aula. A dimensão da informação presente no material analisado enfatiza o professor como alguém que necessita ter domínio de saberes para desempenhar seu trabalho e estabelecer rotinas, de modo a lidar com os imprevistos da prática docente. Sugere informações acerca da profissão como desrespeitada pelos alunos e seus familiares. Destaca que o professor possui uma rotina marcada pela sobrecarga de trabalho, falta de recursos e material didático, excesso de exigências do sistema educacional e/ou das famílias dos alunos, tendo, ainda, que lidar com episódios de indisciplina e violência no espaço escolar.

As representações sociais apresentadas nas imagens e comentários deste artigo discutem o cotidiano dos(as) professores(as), enfatizando os desafios diários que enfrentam no 
desenvolvimento do seu trabalho a partir de dois eixos de sentido: Falta de recursos materiais $e$ didáticos e Excesso de exigências.

\subsection{Falta de recursos materiais e didáticos}

Este eixo aborda os desafios da rotina da prática docente através da precariedade dos recursos e equipamentos nas escolas, de tal modo que o professor chega a providenciá-los por conta própria. São analisadas duas imagens (um meme ${ }^{1}$ e outra com frase anônima), e oito comentários (quatro publicados por mulheres e quatro por homens) apresentados abaixo:

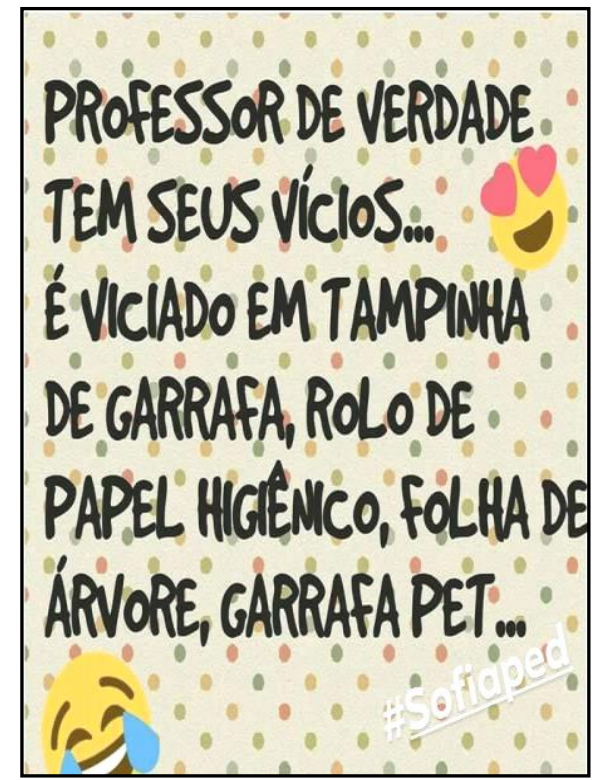

Imagem A: Fabricação de material didático. Fonte: Professores Sofredores, Facebook.

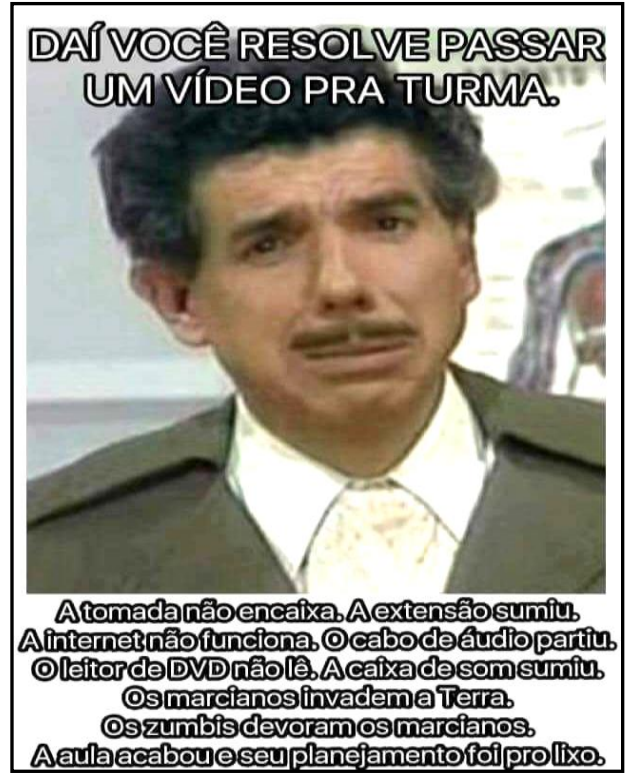

Imagem B: Precarização dos recursos didáticos. Fonte: Profissão Professor, Facebook

A imagem $\mathrm{A}^{2}$ foi publicada na página Professores Sofredores, em agosto de 2018, e obteve o total de 1.600 curtidas e 1.000 compartilhamentos. Traz uma frase anônima que destaca o professor como colecionador de objetos variados que, posteriormente, venham a ser utilizados como recursos didáticos. A imagem $\mathrm{B}^{3}$ foi publicada na página Profissão Professor, em fevereiro de 2018 , e obteve o total de 3.800 curtidas e 3.000 compartilhamentos. É um meme

\footnotetext{
${ }^{1}$ Meme é um tipo de publicação de tom jocoso e caricato bastante conhecido e utilizado na internet, referindo-se ao fenômeno de "viralização" de uma informação, ou seja, qualquer vídeo, imagem, frase, ideia, música e etc., que se espalhe entre vários usuários rapidamente, alcançando muita popularidade.

${ }^{2}$ Disponível em: https://www.facebook.com/ProfessoresSofredoresGss/photos/a.310268855700675/2051711514889725/?type=3\&theater. Acesso em: 07 set. 2018.

${ }^{3}$ Disponível em: https://www.facebook.com/originalprofissaoprofessor/photos/a.329813757062735/1842483152462447/?type=3\&theater. Acesso em: 18 set. 2018.
} 
e traz a imagem do Professor Girafales, personagem do seriado Chaves ${ }^{4}$, com uma expressão angustiada e, logo abaixo, uma legenda que destaca a imprevisibilidade da rotina da profissão e os problemas que afetam a realização do planejamento do professor.

As imagens A e B destacam que a profissão docente lida com a precarização e ausência de recursos adequados para exercê-la com êxito. Nos comentários, as docentes manifestam atitudes de concordância ao se identificarem com tal representação e sinalizam estratégias diárias que utilizam para lidar com a falta de recursos. Duas professoras indicam que não têm material didático disponível para usar em sala de aula e como solução elas se dispõem a reciclar material considerado como lixo, sucata. Uma delas chega a lamentar tal realidade enfrentada pelos docentes no ambiente escolar. Elas comentam:

Eu. Aproveitamento de sucata é tudo! O lixo vira luxo em sala de aula. (mulher $-\mathrm{RJ})^{5}$.

Professor não tem recurso. Nem material disponível distribuído. Portanto, se vira como pode. Inclui tudo citado. Ah de quem não tem habilidade para criar/inventar. A brincadeira é super válida, mas a realidade é lamentável. (mulher - MT).

Um professor alega que, por precaução, leva para a escola todos os recursos didáticos de que dispõe em casa: "Para evitar esses problemas eu levo minha extensão, aparelho de som, notebook e projetor. Detesto imprevisto, então prefiro levar "tudo" de casa." (homem - SE). Em concordância, outra professora também considera que a solução mais prática é levar o material de casa, porém, para aqueles docentes que não podem, indica como solução dispor sempre de outros planos alternativos de trabalho. Afirma:

Bom para quem tem o bom é levar seu próprio equipamento, mas quem não, formula antes o plano B, C, D, pois o bom professor sempre tem uma carta na manga, para que sua aula não se torne um fiasco. (mulher - PI).

Alguns professores reconhecem a necessidade dos docentes sempre terem um planejamento alternativo, pois os imprevistos negativos são comuns na rotina de trabalho, comentam: "Todo professor que planeja uma atividade como esta, por segurança, tem sempre que planejar outra atividade como segundo plano." (homem - ES); "Um professor sem plano B??? Não consigo. Levo

\footnotetext{
${ }^{4}$ El Chavo del Ocho (Chaves, no Brasil) é um seriado de televisão mexicano criado por Roberto Gómez Bolaños (conhecido em seu país como Chespirito) produzida pela Televisa. O sucesso da série foi tanto que, em 1973, foi distribuído em vários países da América Latina, obtendo altos índices de audiência. Disponível em: https://pt.wikipedia.org/wiki/El_Chavo_del_Ocho. Acesso em: 17 mar. 2019.

${ }^{5}$ Os comentários foram transcritos da forma em que estavam apresentados nas referidas publicações de modo a conservar a estrutura de comunicação usada nas páginas do Facebook. Eles estão codificados pelo gênero e localização geográfica do autor do comentário, dados que foram identificados nos seus Perfis Públicos de Usuário da rede social.
} 
sempre a caixa de ferramentas completa em todas as minhas aulas". (homem - AL).

O professor que faz o comentário abaixo deixa claro de qual o recurso didático lança mão, ou seja, suas próprias habilidades de escrita e desenho que foram aperfeiçoadas no exercício docente. Ele revela não ser adepto dos recursos tecnológicos:

Eu escrevo com giz, no quadro de ardósia... Não me incomoda o pó! [...] Ilustro com imagens que guardei, exemplifico com esquemas que aprendi a desenhar e a aperfeiçoar... Tenho truques que não falham e que eles adoram [...]. (homem - RS).

Conforme indicado pela professora do comentário abaixo, ela só dispõe de certos recursos didáticos porque os compra do próprio salário:

É isso mesmo, eu só passei vídeos para os meus alunos durante esses últimos 10 anos.... porque tenho um projetor, que paguei na época 4 mil reais.... e que nunca recebi esse valor de volta, mas só assim poderia manter o padrão das minhas aulas. Deus ajude os educadores!!!!! (mulher - PA).

Os comentários reiteram que os professores lidam diariamente com a precariedade e a falta de recursos didáticos e que eles vão desenvolvendo estratégias para superar essas dificuldades, seja produzindo e/ou comprando tais materiais ou aperfeiçoando suas habilidades técnicas de escrita e desenho e utilizando outros recursos didáticos. Destacam a importância do planejamento das aulas como uma forma de prever possíveis dificuldades e tentar evitá-las mediante um plano alternativo.

Balinhas et al. (2013), ao estudarem a precariedade das escolas e seu impacto na rotina docente, apontam que carências, salas de aula sem reboco e sem pintura, praças e pátios abandonados, móveis quebrados, recursos didáticos de baixa qualidade ou inexistentes, baixos salários e longas jornadas de trabalho são imagens que circulam nas comunicações das docentes. Muitas vezes, os docentes desenvolvem suas atividades em condições de trabalho quase inviáveis. Isto tem levado à criação própria de materiais, sendo a improvisação e a criatividade alguns dos recursos mais usados para atenuarem tal situação. A experiência de trabalhar com poucos recursos ou com materiais de baixa qualidade torna comum que professoras e escolas recorram a produtos descartados por outros, tais como livros e revistas, reciclando o lixo limpo em material didático.

Pizzi, Araújo e Melo (2012) ressaltam que algumas escolas do país apresentam situações precárias em relação a aspectos de infraestrutura física, equipamentos e recursos didáticos. $\mathrm{O}$ quadro se agrava devido às limitadas políticas de valorização docente, como os baixos salários, jornadas de trabalho exaustivas, formas precárias de contratação de professores e a falta de 
planos de carreira compatíveis com a sua importância social. Alguns desses problemas são mais visíveis e outros são sutis, no entanto eles afetam a saúde física e psicológica do docente.

\subsection{Excesso de exigências}

Este eixo trata dos desafios da rotina dos (as) professores (as) atrelados à sobrecarga do trabalho, seja pelas demandas da rotina escolar ou exigências do sistema educacional. Compõe duas imagens (um meme e outra com comando ao receptor) e sete comentários, sendo cinco publicados por mulheres e dois por homens. Abaixo, trazemos os exemplos:

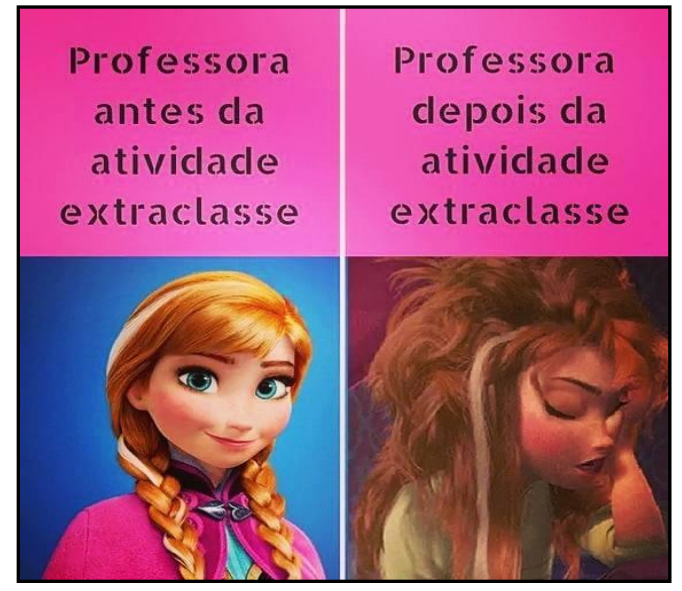

Imagem C: Antes e depois das atividades. Fonte: Profissão Professor, Facebook.

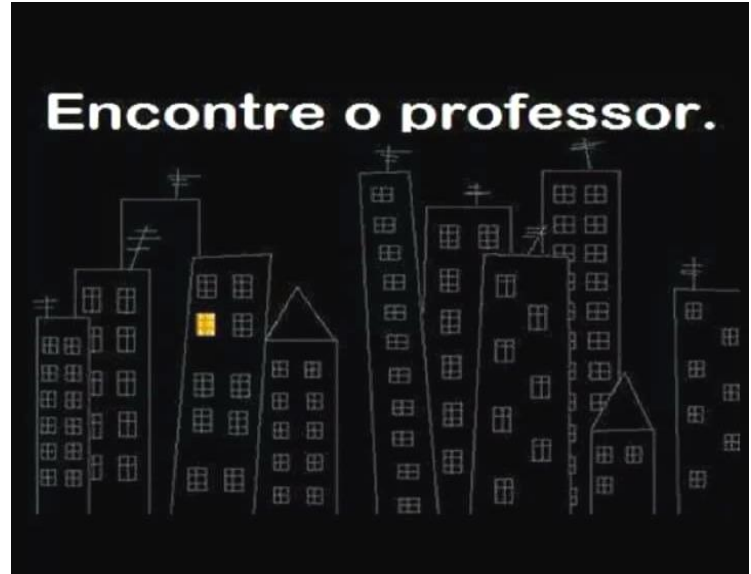

Imagem D: Professor trabalhando até tarde. Fonte: Profissão=Professora, Facebook.

A imagem $\mathrm{C}^{6}$ foi publicada na página Profissão Professor, em setembro de 2018 e obteve o total de 158 curtidas e 122 compartilhamentos. É um meme que ironiza sobre o estado de exaustão da professora antes e depois da realização de uma atividade, usando a personagem Anna, do filme Frozen ${ }^{7}$. A imagem apresenta uma comparação da professora em dois momentos. Antes de realizar uma atividade, apresenta-se com cabelo arrumado, maquiagem e roupas alinhadas, e depois da atividade finalizada, na qual a professora se encontra exausta e desalinhada, com cabelos assanhados e roupa amarrotada, fazendo uma alusão ao desgaste decorrente do trabalho docente.

${ }^{6}$ Disponível em: https://www.facebook.com/originalprofissaoprofessor/photos/a.329813757062735/2122699614440798/?type=3\&theater. Acesso em: 18 set. 2018.

${ }^{7}$ É um filme de animação musical estadunidense, sendo o $53^{\circ}$ filme animado produzido pela Walt Disney Animation Studios. Lançado em 2013, a trama é inspirada no conto de fadas A Rainha da Neve, de Hans Christian Andersen, e narra as desventuras das irmãs Anna e Elsa, respectivamente princesa e rainha de Arendelle, reino fictício na Noruega. Arrecadou mais de 1,2 bilhão de dólares nas bilheterias mundiais e, entre vários prêmios, venceu os Oscars de melhor filme de animação e melhor canção original. Disponível em: https://pt.wikipedia.org/wiki/Frozen_(2013). Acesso: 24 mar. 2019. 
Nos comentários, as atitudes de alguns docentes apresentam identificação com a publicação e chegaram a marcar os nomes de colegas, como por exemplo: "Olha, (insere nome da colega), nós depois da semana das crianças". (mulher - localização desconhecida). De forma um tanto saudosista, outro professor se posiciona sobre a realidade do trabalho docente que, segundo ele, em outros tempos costumava ser respeitado, diferente da realidade que vê hoje em dia: "Acabou-se o tempo que o professor era respeitado em classe, hoje o professor sai dessa forma, exausto". (homem - localização desconhecida).

A imagem $\mathrm{D}^{8}$ foi publicada na página Profissão=Professora, em abril de 2017, e obteve o total de 1.100 curtidas e 715 compartilhamentos. É uma imagem com comando ao receptor e traz, em fundo escuro, um desenho de vários prédios à noite. Em um deles, apenas a janela de uma das residências encontra-se com a luz acesa, sugerindo que ali reside um professor e que, possivelmente, ficou acordado até tarde fazendo atividades referentes à docência, como, por exemplo, planejando aula, preparando e/ou corrigindo atividades. Nos comentários, há um professor que confirma essa realidade de muitas demandas/exigências da profissão, porém, ele argumenta que o que move o professor a dedicar-se ao trabalho é o amor, o desejo de transmitir conhecimentos e a esperança:

Ser professor é amar as pessoas e querer dividir conhecimentos! É saber que apesar de tantas dificuldades ainda há a liberdade para mostrar um horizonte! É ter esperança dentro do coração. (homem - RJ).

Há três professoras que se identificam e concordam com o docente representado na imagem e ressaltam o tipo de atividade que eles devem estar fazendo, reforçando que essa parece ser a rotina dos professores. Afirmam: “Corrigindo provas e fazendo planejamento. É desse modelo! Mas eu amo!!!!” (mulher - DF); "Exatamente onde tem a luz acesa, e é claro que está fazendo algum trabalho de escola". (mulher - RO); "Eu! São 4:20h e vou dormir agora!" (mulher - AL).

Outra professora não se reconhece na imagem, pois, segundo ela, o professor (que pode está retratado na imagem D) estaria em situação social privilegiada. Conforme explicita, o baixo salário do professor não lhe proporciona a qualidade de vida que deseja. Comenta: "Esse professor tem bom salário pra morar no penúltimo andar do prédio. Diferente de mim que mal consigo pagar um aluguel." (mulher - TO).

Rosso e Camargo (2012) discorrem sobre a exaustiva rotina docente de preparar aulas,

${ }^{8}$ Disponível em: https://www.facebook.com/Profissaoprofa/photos/a.468665999810665/156477$\underline{1680200086 / \text { type }=3 \& \text { theater. Acesso em: } 19 \text { set. } 2018 .}$ 
organizar atividades complementares e material didático, planejar e corrigir provas e trabalhos, assim como preencher relatórios. Essas atividades, em geral, ocupam os horários que deveriam ser destinados à atualização pedagógica, ao descanso e ao convívio social. Destacam, ainda, o desgaste decorrente da precariedade das condições materiais de trabalho e relações adversas do cotidiano da profissão, que têm abalado a saúde física e emocional do professor.

A dinâmica do trabalho docente, em sua execução, contempla o consumo da força produtiva e, nas pausas de descanso, o professor realiza sua recuperação, retornando à prontidão inicial. Porém, se o descanso não acontece, o professor vai gradativamente deteriorando a sua capacidade laboral. Assim, na base desse desequilíbrio entre o investimento e a sua recuperação, o trabalhador perde, pouco a pouco, a capacidade e a qualidade no trabalho, promovendo a apreensão na docência como sobrecarga. (ROSSO; CAMARGO, 2012).

Na mesma direção, Mandú e Aguiar (2013) argumentam que a não atratividade da carreira docente pode estar relacionada às condições salariais e de trabalho do professor, à carga excessiva de trabalho devido ao tempo despendido em planejamento, confecção e correção de atividades e provas, além da dupla jornada de trabalho que muitos professores enfrentam para complementar sua renda, trabalhando em dois ou mais turnos.

Os resultados expressam o contexto das práticas dos professores, os limites materiais e didáticos das escolas e sala de aula, o improviso dos docentes e as alternativas das quais lançam mão no dia a dia de suas práticas. Sabemos que é no universo sociocultural que estão e são continuamente produzidas as representações sociais. Como diz Jodelet (2001), se quisermos compreender por que uma pessoa se comporta de um jeito e não de outro devemos ver as relações sociais embutidas em seu cotidiano. Assim, podemos dizer que esse quadro de dificuldades materiais enfrentadas pelo professor, aliado aos outros problemas vividos na escola, favorece a construção de representações sociais marcadas pelo descontentamento e desencanto para com a profissão, mais adiante discutidos.

\section{CONSIDERAÇÕES FINAIS}

Aferimos que as representações sociais sobre os desafios na rotina docente enfatizam a precariedade das condições de trabalho presente na falta de recursos materiais e didáticos, assim como os sentimentos de sobrecarga de trabalho causados pelo excesso de exigências diárias.

Foi possível identificar como atitudes positivas em relação à docência um sentimento ambíguo de amor pela profissão e esperança de um futuro melhor. Como atitudes de cunho negativo, se destacam os sentimentos de sobrecarga e exaustão devido ao excesso de demandas. A dimensão da informação enfatiza o professor como alguém que necessita ter domínio de 
saberes para desempenhar seu trabalho e estabelecer rotinas, de modo a lidar com os imprevistos da prática docente. Sugere a profissão como desrespeitada e destaca que o professor enfrenta uma rotina marcada pela sobrecarga de trabalho, falta de recursos e material didático, excesso de exigências do sistema educacional e/ou das famílias dos alunos.

Segundo Nóvoa (2017), aprender a ser professor exige um trabalho metódico, sistemático, de aprofundamento de dimensões centrais, sendo uma delas a compreensão de que um docente tem de se preparar para agir em um ambiente de incerteza e imprevisibilidade, pois, no cotidiano das escolas, os professores são chamados a responder dilemas que não têm uma resposta pronta e que exigem uma formação que os permita estarem à altura das responsabilidades.

Rosso e Camargo (2012) reforçam que a exaustão no trabalho docente pode ser uma decorrência das mudanças globais, do contexto do trabalho, das reformas do sistema educacional e das condições de trabalho propriamente ditas. Do contexto global, destacam as mudanças aceleradas impostas pela vida moderna, geradoras de tensões e de desorientações. Associadas a elas, estão as reformas educativas que criam novas demandas e atribuições. Mudanças que raramente são acompanhadas de formação, estrutura e gestão para implantá-las. Nas últimas décadas, essas situações têm conduzido à intensificação do trabalho e à precarização da docência.

Os achados da pesquisa também dialogam com outros estudos sobre a docência no âmbito da internet. Dieb, Araújo e Vasconcelos (2014) apontam que tais representações sociais que circulam sobre o professor nessas páginas do Facebook podem se apresentar em um tom jocoso, mas, cuja intenção parece ser a de amenizar as controvérsias em torno do papel social do professor, "visto simultaneamente como aquele que ocupa a mais sublime das profissões (o magistério), mas que não tem o reconhecimento social e financeiro que merece, sendo, por este motivo, um profissional fracassado" (DIEB; ARAÚJO; VASCONCELOS, 2014, p. 724).

Sendo repleta de imprevistos, a rotina docente exige uma prática dos professores marcada pela resiliência para inventar com o que tem à disposição e ter sempre à mão alternativas para o imprevisível ou inviável. No quadro geral do professorado brasileiro, isto parece impossível, contudo, ele não seria de todo desanimador. A título de exemplo, podemos citar o estudo etnográfico desenvolvido por Rezende (2016) sobre a resiliência na prática de quatro professoras de escolas públicas do Recife. Os resultados indicaram que essas professoras demonstram superar limites, enfrentar desafios, romper preconceitos e, assim, conseguem conviver com os infortúnios da profissão. Na visão da autora, tais manifestações de resiliência contribuem para humanização dos sujeitos no contexto escolar. 
Em perspectiva semelhante, destacamos a pesquisa desenvolvida por Araújo e Pereira (2017) sobre o bem-estar docente entre professoras, também, na Rede Municipal de Recife-PE. Os achados do trabalho revelam que, mesmo em meio a um contexto de desvalorização e vulnerabilidade da profissão, é possível o docente se manter íntegro e com disposição para superar as dificuldades e desafios da realidade escolar pública em uma condição de bem-estar.

Com base no exposto, é possível admitir que as representações sociais de professores em suas comunicações na rede social Facebook apresentam o professor como um profissional que lida com uma rotina sobrecarregada, ocasionada por diversas exigências diárias do cotidiano escolar. São variadas as demandas da prática em sala de aula, como, por exemplo, planejamento de aulas e atividades, correção de tarefas e provas, organização de eventos da escola e até mesmo assumir o trabalho de outro colega professor. No geral, o excesso de atividades obriga o docente a abrir mão do seu momento de descanso ou lazer para dar conta de tudo que lhe é cobrado. Os desafios da rotina da prática aqui analisados expressam representações sociais da profissão docente como sendo exaustiva, precária e desvalorizada.

Os achados da investigação apresentados neste artigo indicam que as representações sociais da profissão docente veiculadas no Facebook sugerem os limites da rotina profissional do professor. Os elementos que comprometem o cotidiano docente aqui explicitados são indicativos de que não se deve culpabilizar unicamente o docente pelos problemas educacionais. Quando agimos dessa forma, estamos ignorando os variados obstáculos interpostos ao exercício da profissão na atualidade.

\section{REFERÊNCIAS}

ARAÚJO, Camila Afonso Ferreira. Bem-estar docente: investigando profissionais nessa condição na escola pública. 2017. Trabalho de Conclusão de Curso (Licenciatura em Pedagogia) - Centro de Educação, Universidade Federal de Pernambuco, Recife, 2017. p. 0128.

ARRUDA, Ângela. Representações Sociais: dinâmicas e redes. In: ALMEIDA, Angela Maria. Maria de Oliveira.; SANTOS, Maria Fátima Souza.; TRINDADE, Zeidi A. (Orgs.). Teoria das Representações Sociais: 50 anos. Brasília: Technopolitik, 2011. p. 355-369.

BALINHAS, Vera Lúcia Gainssa et al. Imagens da Docência: um estudo sobre o processo de trabalho e mal-estar docente. Revista mal-estar e subjetividade. Fortaleza, v. 13, n. 1-2, p. 249-270, mar/jun. 2013. Disponível em: http://pepsic.bvsalud.org/pdf/malestar/v13n12/10.pdf. Acesso em 13 dez. 2020.

BARDIN, Laurence. Análise de Conteúdo. Edição revista e atualizada. São Paulo: Edições 70, 2016. 
BELING, Fernanda. Quais são as dez maiores redes sociais. 2016. Disponível em: https://www.oficinadanet.com.br/post/16064-quais-sao-as-dez-maiores-redes-sociais. Acesso em: 03 jan. 2019.

CASTRO, Thaiz Reis Albuquerque de; MACHADO, Laêda Bezerra. Representações sociais da profissão docente: o estado da produção científica brasileira. In: ENCONTRO DE PESQUISA NACIONAL DE PERNAMBUCO - EpePE, 7., 2018, Recife, Pernambuco. Anais [...]. UFRPE, 2018. p. 01-18.

CUNHA, Arisnaldo Adriano da. Autoria e cooperação na formação de sujeitos nas redes sociais: o caso do ENEM no Facebook. 2016. 233 f. Dissertação (Mestrado em Educação) Programa de pós-graduação em Educação, Universidade Federal de Santa Catarina, Florianópolis, 2016.

DIEB, Messias; ARAÚJO, Júlio; VASCONCELOS, Jamilley L. A representação social de professor em fanpages do Facebook. Linguagem \& Ensino, Pelotas, v.17, n.3, p.705-726, set./dez. 2014. Disponível em:

https://periodicos.ufpel.edu.br/ojs2/index.php/rle/article/view/15311. Acesso em 13 dez. 2020.

FAGUNDES, Mateus Miranda; ZANELLA, Michele; TORRES, Tatiana Lucena. Cidadão em foco: representações sociais, atitudes e comportamentos de cidadania. Psicologia: teoria e prática, v. 14, n. 1, p.55-69, abr. 2012. Disponível em:

http://pepsic.bvsalud.org/pdf/ptp/v14n1/v14n1a05.pdf. Acesso em 13 dez. 2020.

FURTADO, Everley Rosane Goetz. Representações sociais do corpo, mídia e atitudes. 2009. 459 f. Tese (Doutorado em Psicologia) - Programa de Pós-Graduação em Psicologia, Universidade Federal de Santa Catarina, Florianópolis, 2009.

GALLI, Ida. A teoria das representações sociais: do nascimento ao seu desenvolvimento mais recente. Trad. Alexandre Rosado. Revista ADM. MADE, p. 01-14, 2012. Disponível em: http://periodicos.estacio.br/index.php/reeduc/article/viewArticle/900. Acesso em $13 \mathrm{dez}$. 2020.

GIL, Antônio Carlos. Como elaborar projetos de pesquisa. São Paulo: Atlas, 2006.

JODELET, Denise. As representações sociais. Rio de Janeiro: UERJ, 2001.

LENGERT, Rainer. Profissionalização docente: entre vocação e formação. La Salle - Revista de Educação, Ciência e Cultura, v. 16, n. 2, jul./dez. 2011. Disponível em:

https://revistas.unilasalle.edu.br/index.php/Educacao/article/view/195. Acesso em 13 dez. 2020.

LUDKE, Menga.; ANDRÉ, Marli Elisa Dalmásio. Pesquisa em Educação: abordagens qualitativas. São Paulo: EPU, 1986.

MANDÚ, Tamirys Mariana Camarote; AGUIAR, Maria da Conceição Carrilho de. A formação inicial no curso de pedagogia: representações, caminhos e perspectivas dos estudantes. ETD - Educ. temat. digit., Campinas, SP, v. 15, n. 3, p. 560-577, set./dez. 2013. Disponível em: https://periodicos.sbu.unicamp.br/ojs/index.php/etd/article/view/1273. Acesso em 13 dez. 2020. 
MAZZOTTI, Alda Judite Alves.; CAMPOS, Pedro Humberto Faria. Cibercultura: uma nova era das representações sociais? In: ALMEIDA, Angela Maria de Oliveira; SANTOS, Maria Fátima Souza.; TRINDADE, Zeidi Araujo. (Orgs.). Teoria das Representações Sociais: 50 anos. Brasília: Technopolitik, 2011. p.457- 484.

MOSCOVICI, Serge. Representações sociais: investigações em psicologia social. 9. ed. Petrópolis: Vozes, 2012.

NEILPATEL. As redes sociais mais usadas. 2019. Disponível em: https://neilpatel.com/br/blog/redes-sociais-mais-usadas/. Acesso em: 03 jan. 2019.

NÓVOA, Antônio. Firmar a posição como professor, afirmar a profissão docente. Cadernos de Pesquisa, v. 47, n. 166, p. 1106-1133, out./dez. 2017. Disponível em: https://www.scielo.br/pdf/cp/v47n166/1980-5314-cp-47-166-1106.pdf. Acesso 13 dez. 2020.

PIZZI, Cristina Vieira; ARAUJO, Isabela Rosália Lima; MELO, Wanessa Lopes de. A precarização na sala de aula: reflexões sobre seus efeitos na ótica docente. Revista Educação e Cultura Contemporânea, v. 9, n. 18, p. 135-151, 2012. Disponível em: http://periodicos.estacio.br/index.php/reeduc/article/viewArticle/439. Acesso em $13 \mathrm{dez}$. 2020.

RECUERO, Raquel. Curtir, compartilhar, comentar: trabalho de face, conversação e redes sociais no Facebook. Verso e Reverso, v. 28, n. 68, p.114-124, maio/ago. 2014. Disponível $\mathrm{em}$ : http://www.revistas.unisinos.br/index.php/versoereverso/article/view/7323. Acesso em 13 dez. 2020.

REZENDE, Enivalda Vieira dos Santos. Resiliência no contexto da prática pedagógica de professoras de escolas públicas municipais do Recife. 2016. Tese (Doutorado em Educação) Programa de Pós-graduação em Educação, Universidade Federal de Pernambuco, Recife, 2016. Disponível em: https://repositorio.ufpe.br/handle/123456789/25514. Acesso em 13 dez. 2020.

ROSSO, Ademir José; CAMARGO, Brígido de Vizeu. As Representações Sociais do Desgaste no trabalho a partir dos simbolismos associados à docência. ETD - Educ. temat. digit., Campinas, SP v. 14, n. 2, p. 179-200, jul./dez. 2012. Disponível em: https://periodicos.sbu.unicamp.br/ojs/index.php/etd/article/view/1301. Acesso em $13 \mathrm{dez}$. 2020.

SILVA, Lygia de Assis. O uso pedagógico do twitter no desenvolvimento das habilidades para o letramento: possibilidades de comunicação e interação mediadas pelas tecnologias digitais. 2016. 136 f. Dissertação (Mestrado em Educação Matemática e Tecnológicas) Universidade Federal de Pernambuco, Recife, 2016.

TOMAÉL, Maria Inez; ALCARÁ, Adriana Rosecler; DI CHIARA, Ivone Guerreiro. Das redes sociais à inovação. Ci. Inf., Brasília, v. 34, n. 2, p. 93-104, maio/ago. 2005. Disponível em: https://www.scielo.br/pdf/ci/v34n2/28559.pdf. Acesso em 13 dez. 2020. 


\section{SOBRE AS AUTORAS}

Thaiz Reis Albuquerque de Castro é graduada em Pedagogia e mestra em Educação pela Universidade Federal de Pernambuco - UFPE.

E-mail: thaizcastro@ hotmail.com

ORCID: https://orcid.org/0000-0002-6960-7164

Laeda Bezerra Machado é graduada em Pedagogia pela Universidade Federal do Ceará, mestra em Educação pela Universidade Federal de Pernambuco e doutora em Educação pela Universidade Federal do Rio Grande do Norte. É Professora Adjunta do Departamento de Administração Escolar e Planejamento Educacional, Programa de Pós-Graduação em Educação - Núcleo de Formação de Professores e Prática Pedagógica -Centro de Educação - UFPE e líder do Grupo de pesquisa Educação e Representações sociais/CNPq.

E-mail: laeda01@gmail.com

ORCID: https://orcid.org/0000-0002-9524-0319 